\title{
Design Of Web-based Qr-code Absence At The Education Office
}

Fifit Alfiah $^{1}$, Anisa Yondari ${ }^{2}$

Universitas Raharja

Jl. Jenderal Sudirman No.40, Cikokol, Kec. Tangerang, Kota Tangerang, Banten 15117 Indonesia

e-mail: Fifitalfiah@raharja.info ${ }^{1}$, anisa.yondari@raharja.info ${ }^{2}$

To cite this document:

Alfiah, F., \& Yondari, A. (2019). Design Of Web-Based Qr-Code Absence At The Education Office. IAIC Transactions on Sustainable Digital Innovation, 1(1), 26-31. Retrieved from

https://aptikom-journal.id/index.php/itsdi/article/view/11

\begin{abstract}
The need for fast and accurate data processing is needed by every government agency. The Education Office is an administrative administrator in the field of education that requires a fast system for processing data. The attendance system at the Tangerang Regency education office is already using a fingerprint. However, there are still many obstacles that arise due to lack of tools, and damage to the tool so that it often uses manual attendance. The research method used is the method of data collection, and the analytical method used is a form of Unified Modeling Language. The results and objectives of this study are the creation of a system that can facilitate employee and attendance managers to be more effective and efficient.
\end{abstract}

Keywords: Education Office, Attendance, Qr-Code

\section{Introduction}

The development of science and technology today, making information has a very important role in the effort to create progress in all fields. With the availability of information technology, it has been felt easy to get accurate, fast and timely information. Tangerang Regency Education Office is an element of implementing government proposals in the field of education. The Tangerang Regency education office was formed from the merger of several agencies, including the Ministry of National Education, the Office of Education and Culture and part of the Ministry of Information. In accordance with the times of the Tangerang Regency Education Office demands an increase in work discipline. One of the problems that must be addressed is the problem of absenteeism, and therefore an accurate increase in attendance is required by using technology. With this technology, it can improve the administrative field that supports work processes, and simplifies the handling of information needed to monitor employee productivity. Therefore, the Tangerang District Education Office requires an increase in the system, especially for attendance systems using the Qr-Code which is a new innovation in applying technology to employee absences. Later with the existence of this system employees can pass attendance by means of the Qr-Code Scanner on a computer screen that is expected to provide

\section{Research Method}


IAIC Transactions on Sustainable Digital Innovation (ITSDI)

Vol. 1 No. 1 October 2019

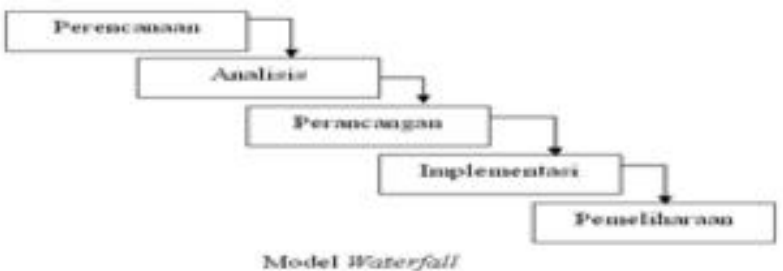

Figure 1. Waterfall

According to Pressman (2015: 42), the waterfall model is a classic model that is systematic, sequential in building software. The name of this model is actually "Linear Sequential Model". This model is often called the "classic life cycle" or the waterfall method

\subsection{Requirement Analysis}

In this study, a direct survey of activities in the attendance of the Tangerang District Education Office will be carried out when conducting data collection.

\subsection{Data collection}

a. Conducting research by observing the activities carried out at checking attendance.

b. Identification of the problem is knowing and determining the problem to be discussed in this study, namely the problem of absenteeism that exists in the education office which is still less effective.

c. In this stage, collecting data by looking for references in books and journals.

\subsection{Literature Review}

In this research has been based on several theories that support this research, namely:

1. This research was conducted by Isma Damayanti (2016). This research was conducted by Damayanti entitled "Development of SIS + Consultation Using Qr Code Scanners as a Consultation Media for College Guidance Lectures". This study discusses the consultation using Qr Code which makes it easy for students to communicate with lecturers by mentioning the ticket code provided by students. Consultation using the Qr Code can facilitate the lecturer in inputting the ticket code provided by students, and all the results of the recording of students' traces of problems can be recorded in SIS +.

2. This research was conducted by Ade Setiawan (2019) entitled "Planning the Web-Based Attendance Information System at SMA Negeri 21 Kabupaten Tangerang". This study discusses absenteeism at SMA 21 which often confuses student absenteeism data that is often tucked, damaged or even lost. Researchers designed a website-based student attendance information system that can help and simplify all processes that exist in the previous attendance system.

3. This research was conducted by Qurotul Aini et al (2017). This study was conducted by Qurotul Aini et al entitled "The Application of Student Qr Code Attendance to Tutoring on YII Framework-based Websites". This study discusses the Qrcode attendance scanning service system to record student attendance well. The PenA (Attendance Assessment) system provides services in the Qrcode scanning attendance process, avoiding fraud committed by students who often leave attendance at their friends. This attendance will record 
IAIC Transactions on Sustainable Digital Innovation (ITSDI)

Vol. 1 No. 1 October 2019

the Nim, Lecturer Discussion, Bombingan Room, Time of Attendance, and the unique Qrcode code.

4. This research was conducted by Mukhamad Taqwa Nuddin and Diana Laily Fithri (2015). This research was conducted by Mukhamad Taqwa Nuddin and Diana Laily Fithri, entitled "Lecturer Assistant Attendance System Using the Android-Based Qr Code Scanner in the Information Systems Study Program at Muria Kudus University". This study discusses the Lecturer Assistant Attendance System which is used to recap the number of Lecturer assistant attendances and also to recap the honorariums received by each teaching assistant based on the presence of the teaching assistant.

\section{Findings}

\subsection{Problem}

Based on the analysis conducted by the author, the problem faced by the employee absentee system that runs at this time in the Tangerang District Education Office is the attendance process that uses fingerprints, there are still often obstacles in inputting data, duplication of data so that employees must report to the attendance so slow their absence and the lack of tools and damage to these tools and the frequent occurrence of manual absences. So according to the need for information about the absenteeism of the employee, this system requires development or improvement to achieve a system that is truly reliable and functions as fully as possible to provide information to the admin.

\subsection{Research Implementation}

The system to be designed is expected to later be able to run or be carried out on a system that is as minimal as possible in order to provide economic benefits. To design this information system, software as a system design media is needed. Among them:
a. Microsoft Windows 10
b. Notepad ++
c. XAMPP
d. Software editor ( PHP dan HTML)

\subsubsection{Display System Design}

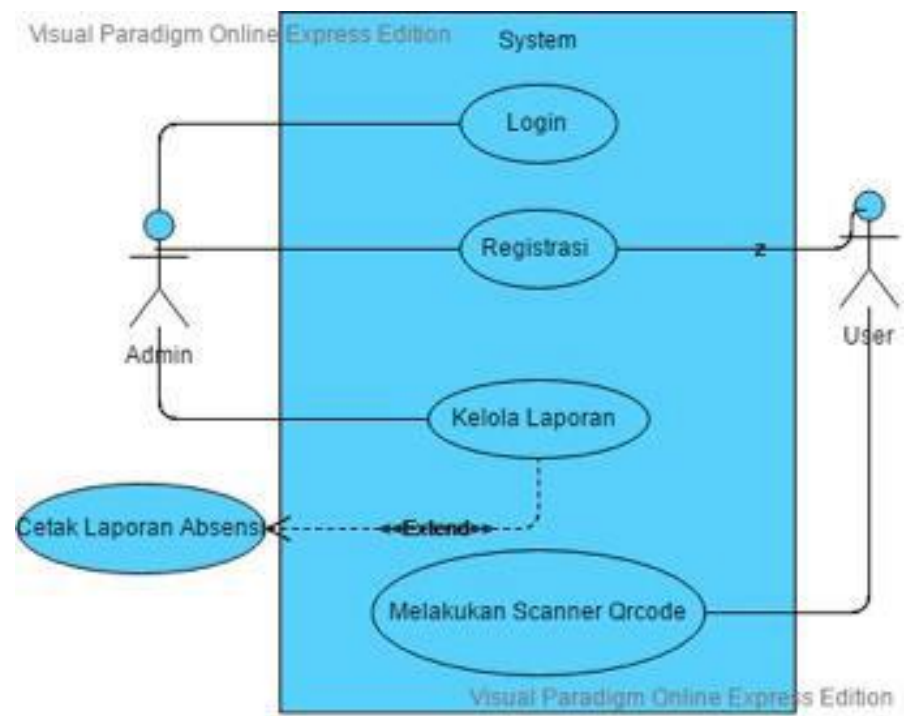

Figure 2. The QrCode Time Attendance Diagram 
IAIC Transactions on Sustainable Digital Innovation (ITSDI)

Vol. 1 No. 1 October 2019

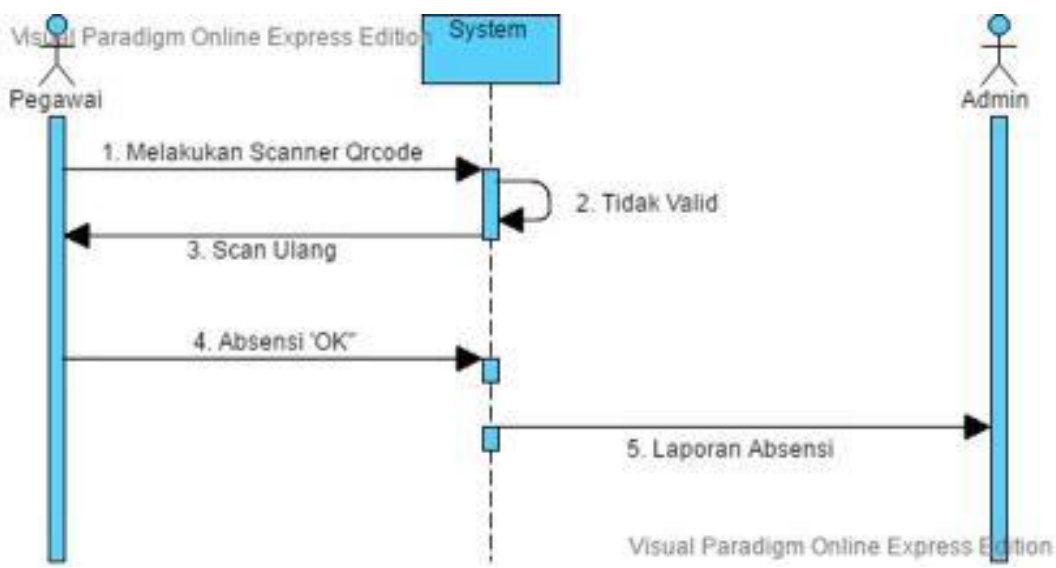

Figure 3. Sequence Diagram of Attendance Process

\subsubsection{Design the Program Display}

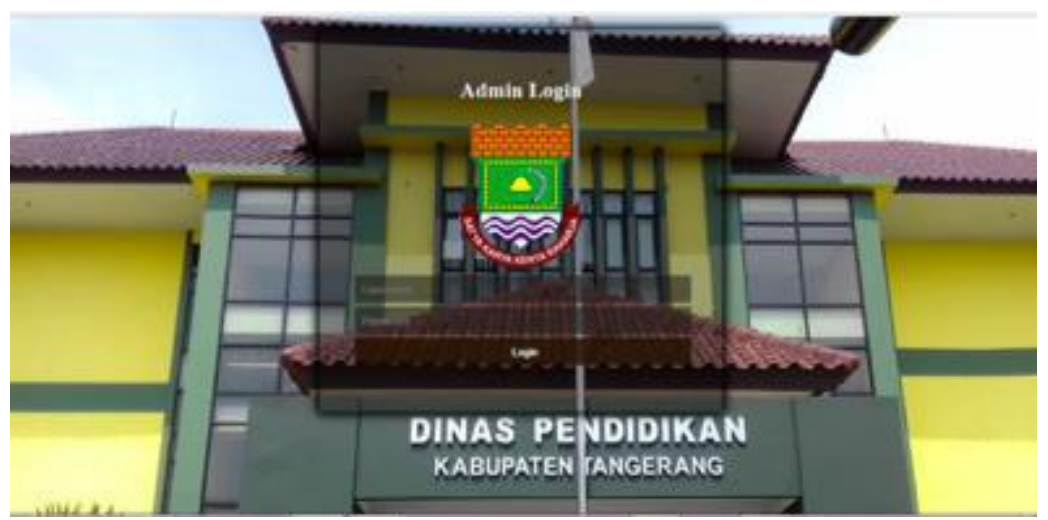

Figure 4. Admin

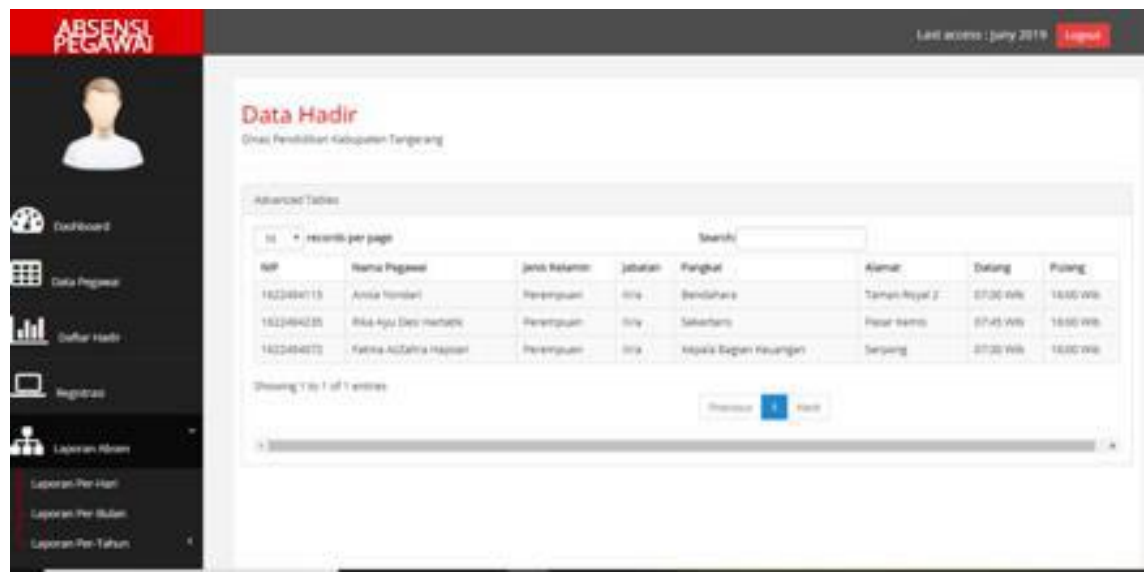

Figure 5. Front page 
IAIC Transactions on Sustainable Digital Innovation (ITSDI)

Vol. 1 No. 1 October 2019
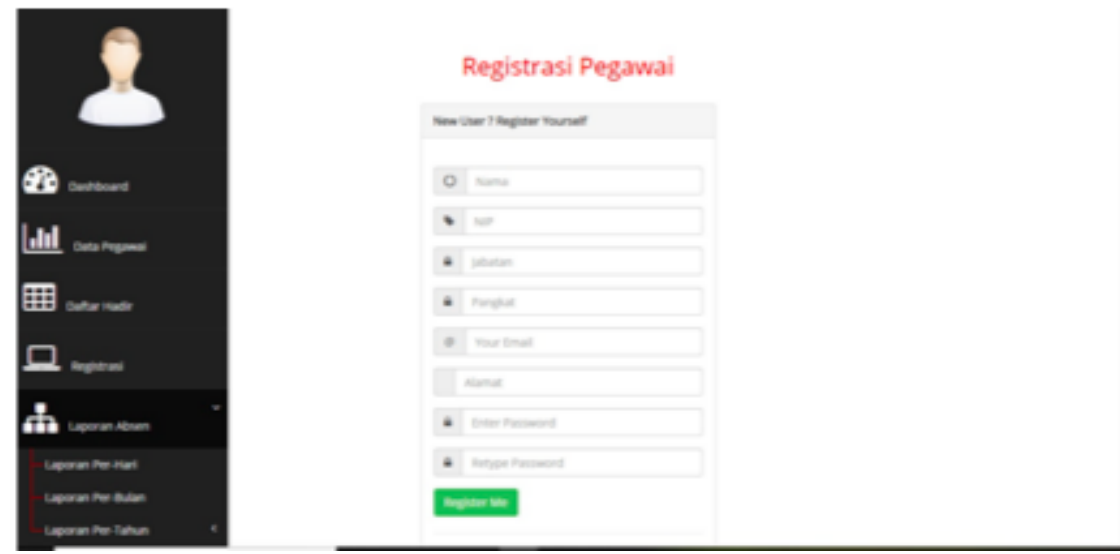

Figure 6. Register a new employee

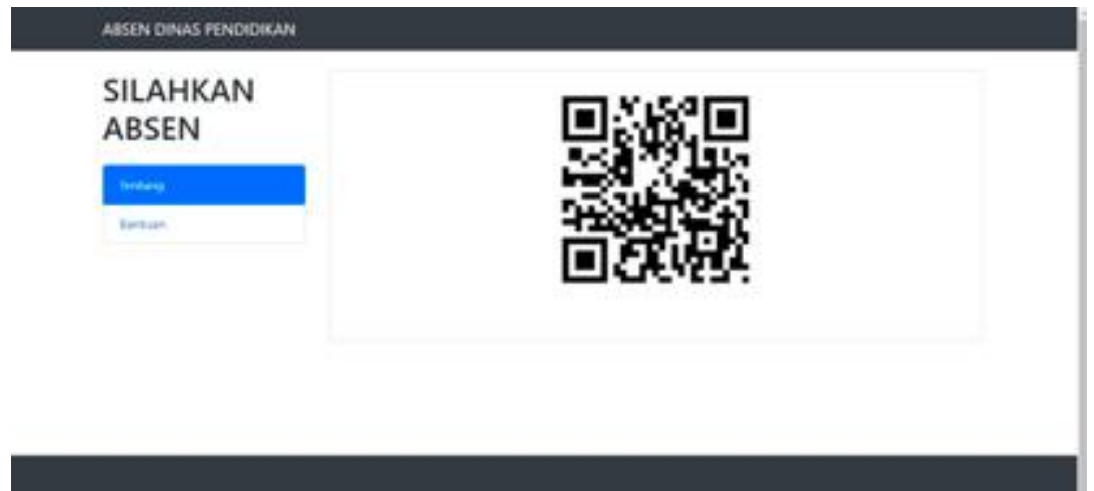

Figure 7. Qr Attendance Code

\section{Conclusion}

1. With this system it is expected that this application can provide detailed and accurate information about the online population system, so that all parties feel helped in getting data effectively and efficiently.

2. The most common obstacle experienced by employees is the absence of attendance due to inaccurate data during fingerprint authentication so that employees cannot be absent and must require re-authentication. And when employees do morning apples every Monday employees cannot be absent so they must require a statement from the section chief.

3. The system to be proposed is a web-based Qr Code attendance system, to be used by employees to simplify the attendance process and minimize errors that often occur at this time.

\section{References}

[1] Ageng Setiani Rafika dkk 2014, Aplikasi Monitoring Sistem Absensi Sidik Jari Sebagai Pendukung Pembayaran Biaya Pegawai Terpusat dengan SAP. ISSN : 1978 - 8282 Vol.8 No.3 - Mei 2015. STMIK Raharja Tangerang. 
IAIC Transactions on Sustainable Digital Innovation (ITSDI)

Vol. 1 No. 1 October 2019

[2] Mukhamad, T.N., dan Diana, L.F. Sistem Absensi Asisten Dosen Menggunakan QR Code Scanner Berbasis Android Pada Program Studi Sistem Informasi Universitas Muria Kudus. ISBN: 978-602-1-1180-21-1 - Prosiding SNATIF Ke- 2 Tahun 2015. Fakultas Teknik- Universitas Muria Kudus.

[3] Qurotul Aini dkk 2017. Penerapan Absensi QRCode Mahasiswa Bimbingan Belajar pada Website berbasis YII Framework. Jurnal IImiah SISFOTENIKA Vol. 7 No. 2, Juli 2017.

[4] Isman Damyati 2016. Pengembangan SIS+ Konsultasi Menggunakan Qr Code Scanner Sebagai Media Konsultasi Perkuliahan Bimbingan pada Perguruan Tinggi. Skripsi Perguruan Tinggi Raharja - 2016.

[5] Setiawan, Ade 2019. Perancangan Sistem Informasi Absensi Berbasi Web pada SMA Negeri 21 Kabupateng Tangerang. Skripsi Perguruang Tinggi Rahaja- 2019.

[6] Arisanti,d., 2015, Perancangan Sistem Informasi Pendataan Penduduk Berbasis Web Menggunakan Metode Waterfall Pada Desa Bogorejo Kecamatan Gedongtataan.

[7] Wijayanti, Esa. 2014. Perancangan Sistem Informasi Absensi Pegawai Pada Kantor Kecamatan Batu Ceper Tangerang. 